\title{
CHALLENGING ENVIRONMENTAL EXPOSURES THROUGH DISCRIMINATION LAW IN EUROPE
}

Refia KAYA*

Araştırma Makalesi

\begin{abstract}
Environmental problems continue becoming more apparent in Europe. Many people are exposed to environmental harms such as heatwaves, chemicals, polluted air, and contaminated water. This article aims to discuss whether it is feasible to frame environmental exposures as discrimination issues and if it is feasible whether European discrimination law can be/is used to challenge environmental exposures. For this, both non-legal and legal sources are analysed. The article identifies the possible internal limitations of discrimination law that have been preventing its application in the domain of environment so far. It is argued that discrimination law has a significant potential despite the limited number of legal cases that link environmental exposures and discrimination in Europe.
\end{abstract}

Keywords: Environmental Exposures, Equality, Discrimination Law, Europe

\section{Zararlı Çevresel Etkilerle Mücadelede Avrupa Ayrımcılık Hukukunun Kullanılması}

$\ddot{O} z$

Avrupa'da çevresel sorunlar daha görünür olmaya devam etmektedir. Birçok insan sıcak hava dalgalarl, kimyasallar, hava kirliliği ve su kirliliği gibi çevresel zararlara maruz kalmaktadır. Bu makalenin amacı zararlı çevresel etkilerin ayrımcilık olarak nitelendirilmesinin uygunluğunu ve Avrupa ayrımcllı yasağ hukukunun zararl çevresel etkilerle mücadelede uygulamasını tartışmayı amaçlamaktadır. Bunun için hukuki olan ve olmayan kaynaklardan yararlanilmıştır. Makale, ayrımcllık hukukunun şimdiye kadar çevresel alanda kullanımını kısıtlayan sınırlamalarını tespit etmektedir. Avrupa'da ayrımcılık ve çevresel etkiler arasında bağlantı kuran sınırlı sayıda hukuki dava olmasına rağmen ayrımcılık hukukunun ciddi bir potansiyeli olduğunu savunulmaktadır.

Anahtar Kelimeler: Çevresel Etkiler, Eşitlik, Ayrımcılık Hukuku, Avrupa

* Dr., LLM., Belçika Louvain Üniversitesi, E-Posta: refia.kadayifci@uclouvain.be , ORCID: 0000-0001-6434-3887.

Makalenin Gönderilme Tarihi: 01/01/2021 Kabul Edilme Tarihi: 27/05/2021 


\section{Introduction}

The environment can be broadly defined as "the surroundings or conditions in which a person, animal, or plant lives or operates". "There could be different types of problems related to the pollution and degradation of the environment or the use of harmful substances. ${ }^{2}$ These include but are not limited to the issues of procedural fairness in environmental matters ${ }^{3}$, rights of nature ${ }^{4}$ and negative impacts of pro-environmental policies. ${ }^{5}$ This article particularly focuses on environmental exposures stemming from environmental pollution or degradation, such as lack of access to safe drinking water and clean air, exposure to chemicals, or climate changerelated catastrophes.

1 Oxford Online Dictionary, retrieved fromhttps://www.lexico.com/en/definition/environment

(last accessed 15.04.2021).

2 Pollution can occur in various environments, such as the living environment, work environment, or learning environment. Harmful environmental substances do not always appear through pollution of natural resources. For example, many harmful environmental substances in work environments appear because of some technologies or chemicals that are used for service/production.

3 Some groups of individuals may not have enough voice to be represented before the courts or in the decision-making process. Concerns on procedural inequalities were incorporated into the social policy of Europe in the early 2000s following the adoption of the Aarhus Convention. The Aarhus Convention predominantly secures procedural justice, which is concerned with fairness or equity to access environmental decision-making processes.

See http://ec.europa.eu/environment/aarhus// (last accessed 15.04.2021). Also see Kishan Khoday and Leisa Perch. "Green Equity: Environmental Justice for More Inclusive Growth." Policy Research Brief, International Policy Centre for Inclusive Growth 19 (2012).

4 Roderick Frazier Nash. The Rights of Nature: A History of Environmental Ethics. University of Wisconsin Press, 1989.

5 Policies to eliminate the negative effects of environmental exposures can have disparate impacts on individuals with socially salient traits. For example, currently, environmental policies lead to a dilemma in countries where fuel and non-electric cars are being highly taxed. Such pro-environmental measures disadvantage the socio-economically least welloff individuals. This is a problem of conflicting rights that appears when the state aims to protect the general environmental well-being but degrades the situation of socially vulnerable individuals. Such cases lead to many questions. Can people put the quality of their current living conditions first, rather than considering the long-term effects of environmental degradation? Can the state oblige people to give up their non-environmental lifestyles, even if some people cannot afford a pro-environmental life? Can people be obliged to buy organic food by paying higher prices at some point?These questions are very important, but are not within the scope of this article.

In the literature, the above-mentioned different types of environmental problems are usually addressed through the concept of "environmental justice". This article does not intent to use this broad concept. 
Environmental exposuresmay affect individuals unequally. Some people may enjoy good environmental quality, while others may be structurally exposed to environmental pollution and be unequally unable to avoid exposure. Moreover, some people may be physically more resilient, i.e. healthy adults, while others may be less resilient and, therefore, vulnerable, i.e. children,to environmental pollution. In some of these unequal impact cases, it can be shown that those who face environmental exposures are individuals with a particular socially salient trait. ${ }^{6}$ This article looks at environmental exposures that involve the disadvantaged situations of those with socially salient traits that make them environmentally vulnerable. ${ }^{7}$ It aims to explore whether environmental exposures can be problematised underdiscrimination law in general and European discrimination law (European Union (EU) and European Convention of Human Rights (ECHR)) in particular. ${ }^{8}$

In this regard, section Iexplains the motivation for addressing environmental exposures through discrimination law. The main question of this section is whether it is feasible to frame environmental exposures as equality and discrimination issues.Section II returns to the law and explores the legal approaches to the link between environmental exposures and discrimination law and the potential of discrimination law. Section III and IVdeepen on the legal aspect. These sections respectively explore how can environmental exposures in working and living environments be problematised and whether European discrimination law is useful to address the explained problems.

6 Discrimination law does not focus on all possible kinds of traits, but rather only on "socially salient traits". Socially salient traits give their possessors an identity that makes the possessors salient. For example, eye colour is a trait. However, eye colour is not always something that individuals identify themselves with. The decisiveness of a trait with regard to accessing advantages or disadvantages in society helps in identifying whether a trait is socially salient or not. For example, if eye colour is not a trait that determines the social advantages and disadvantages that groups of people have, eye colour may not be considered a socially salient trait that discrimination law generally concerns itself with. For a comprehensive discussion on this issue see Kasper Lippert-Rasmussen, Born Free and Equal?: A Philosophical Inquiry into the Nature of Discrimination. Oxford University Press, 2014: 30-36; Tarunabh Khaitan, A Theory of Discrimination Law. Oxford University Press, 2015: 32-38.

7 The article particularly highlights those groups of a particular race, sex, belief, dis/ability and age.

8 In the actual law and in the legal literature, discrimination law is also referred to as "antidiscrimination law" and "non-discrimination law", which shows that this law is against discrimination. It is also referred to as "equality law" to show that it promotes equality. For the sake of clarity and ease I use the term "discrimination law". 


\section{Bridging Environmental Exposures and Discrimination}

The motivation behind framing environmental exposures as discrimination issues arises from the observation that many non-legal studies link environmental exposures to (in)equality and discrimination. However, there are not many legal studies and even fewer legal cases exploring this link. This section aims to briefly describe the non-legal approaches that motivate the idea of this article, namely using discrimination law to address environmental pollution.

Fineman develops the concept of the "vulnerable subject". Fineman's theory suggests that all individuals can potentially be susceptible to destructive external forces and internal disintegration. ${ }^{9}$ It is inappropriate that social policies focus on a "liberal subject" who is assumed to have capabilities that real humans are deprived of. Instead, the vulnerable subject should be placed at the core of social policies. Fineman argues that, in this way, states would be more responsive to the vulnerabilities of people. Harris then adopts this approach to argue that the vulnerable subject theory is crucial for redefining the environmental obligations of the state. ${ }^{10}$ The equality and discrimination approach to environmental issues is in line with these arguments. It requires focusing on those with socially salient traits that make them particularly disadvantaged with regard to environmental exposures.

The extent of an individual's reaction to environmental exposure, which is based on physical or social conditions, determines one's environmental vulnerability. ${ }^{11}$ Environmental exposures could potentially affect the life quality of anyone who is exposed to pollution. They can be linked to discrimination when such exposures are disproportionality affecting individuals with a socially salient trait because of either the physiological or the social vulnerability of these individuals. Various dynamics contribute to one's environmental vulnerability. Socially salient traits like young or old age, disability, sex, pregnancy, beliefs, and economic situation may put individuals into a vulnerable situation. ${ }^{12}$

9 Martha Albertson Fineman, "The Vulnerable Subject: Anchoring Equality in the Human Condition." Yale Journal of Law \& Feminism 20, no. 1 (2008): 2.

10 Angela P. Harris, "Vulnerability and Power in the Age of the Anthropocene." Washington and Lee Journal of Energy, Climate, and the Environment 6, no. 1 (2014).

11 Ibid.

12 UNEP. "Women and Chemicals: The Impact of Hazardous Chemicals on Women: A Thought Starter Based on an Experts'Workshop." 2016. 
Environmental exposure can be linked to discrimination in various domains. Working environments may involve chemicals or substances that are only harmful to workers in a vulnerable situation. Usually, occupational exposure limits are set in Europe to minimise everyone's exposure to hazardous substances without considering those who are more vulnerable than average. ${ }^{13}$ However, some factors, such as age or specific health conditions, might aggravate the effects of exposure even if it is within the general limits. For example, children can be more fragile to a certain level of pollution that does not harm healthy adults.

Environmental exposures may also affect individuals in their living environments. This could be private living environments, like the neighbourhoods in which their houses are located. For example, people may be exposed to air pollution caused by a nearby industrial facility. Environmental exposure can also affect individuals when they are outside their private living environment. For example, people may be exposed to pollution in outdoor spaces if the air quality is bad everywhere. On a larger scale, the number of cars in traffic and the types of fuels being used, the source of energy being used in households or workplaces, the proximity of industrial facilities to cities, etc., can cause environmental exposures.On a smaller scale, environmental exposures can stem from cigarette smoke in public places such as restaurants, parks, or streets if there are not any regulations restricting the areas for smoking.

There are numerous reports and social and scientific studies that reveal the disproportionate burden placed on individuals with socially salient traits by pollution of the environment. The first reports were published by the end of the 1970s in the United States (US). Two national landmark reports revealed that the vast majority of hazardous landfills were located in the vicinity of black and Hispanic neighbourhoods. ${ }^{14}$ These reports documented

13 Council Directive 98/24/EC of 7 April 1998 on the protection of the health and safety of workers from the risks related to chemical agents at work, OJ L 131, 5.5.1998: 11-23.

14 A study conducted by the US General Accounting Office revealed that people of colour constituted the majority of the population in three out of four communities where landfills were located. GAO. "Siting of Hazardous Waste Landfills and Their Correlation with Racial and Economic Status of Surrounding Communities." 1983.

A study by the United Church of Christ Commission for Racial Justice found that three out of every five blacks and Hispanics lived in communities with uncontrolled hazardous waste sites. The famous environmental justice movement against discrimination in the domain of the environment with regard to the distribution of environmental hazards started following these social reports. UCC. "Toxic Wastes and Race in the United States: A National Report on the Racial and Socio-Economic Characteristics of Communities with Hazardous Waste Sites.", 1987. 
both racial and socio-economic demographic patterns associated with the settings of the waste sites. ${ }^{15}$

Distributive justice problems, concerning how environmental goods and bads are distributed among various groups, reported later in Europe. For example, in 2001, a report of the Open Society Institute revealed that in Eastern Europe, certain types of environment-related illnesses occur several times more often amongst Roma people than the general population. ${ }^{16}$ This is because Roma people often live close to polluted areas. ${ }^{17}$

The first comprehensive social study to link the disproportionate environmental burden placed on some populations to "discrimination" was Dumping in Dixie by Robert Bullard in $1990 .{ }^{18}$ Many similar studies followed. ${ }^{19}$ These studies' main concern is environmental racism, i.e. environmental injustices motivated both by race and socio-economic status. Later on, the ecofeminist movement developed social studies on the disparate impacts of environmental degradation on women and children. ${ }^{20}$ The ecofeminist movement puts forward that women and children are more vulnerable to environmental degradation, not mainly because of physiological or biological reasons but because they are often neglected in social policies. ${ }^{21}$ This idea is parallel tothe social model of disability, which

15 A decade after the aforementioned reports were published, the 1994 Executive Order issued by President Clinton directed federal agencies to address disproportionate and adverse human health or environmental effects of their actions on both minority and lowincome populations; see https://www.archives.gov/files/federal-register/executiveorders/pdf/12898.pdf(last accessed 15.04.2021).

16 Open Society Institute, "On the Margins: Roma and Public Services in Romania, Bulgaria and Macedonia." New York, 2001.

17 Ibid.

18 Robert D. Bullard, Dumping in Dixie: Race, Class, and Environmental Quality. Boulder: Westview Press, 1990.

19 Rebecca L Calderon, et al. "Health Risks from Contaminated Water: Do Class and Race Matter?". Toxicology and Industrial Health 9, no. 5 (1993): 879-900; Mary E. Northridge, and Peggy M Shepard. "Environmental Racism and Public Health." American Journal of Public Health 87, no. 5 (1997): 730-32; Kristin Shrader-Frechette, Environmental Justice: Creating Equality, Reclaiming Democracy. Oxford University Press, 2002; Steve Wing, "Environmental Justice, Science and Public Health." Environ Health Perspectives 113 (2005): 54-63; Sacoby M. Wilson, "Environmental Justice Movement: A Review of History, Research, and Public Health Issues." Journal of Public Management \& Social Policy 16, no. 1 (2010).

20 Vandana Shiva, "The Impoverishment of the Environment: Women and Children Last." In Ecofeminism, edited by Maria and Shiva Mies, Vandana, 70-91: Zed Books, 1993; Karen Warren, Ecofeminist Philosophy: A Western Perspective on What It Is and Why It Matters. Rowman \& Littlefield, 2000; Irene Dankelman, Gender and Climate Change: An Introduction. London: Earthscan, 2010.

21 WHO. "Social and Gender Inequalities in Environment and Health." 2010. 
puts forward that disability does not come endogenously but is created exogenously by the social structure. ${ }^{22}$ In analogy, the ecofeminist movement mostly disregards the environmental vulnerabilities that come endogenously. Every kind of vulnerability is mainly considered to be created exogenously by the unjust social structure, which denies socially salient groups like women and children. Hence, social studies mainly establish a link between environmental exposures and some individuals being socially vulnerable.

There is a good number of scientific researches focusing on public health and vulnerable groups. ${ }^{23}$ These studies mostly highlight some individuals being physically vulnerable due to endogenous factors. In this regard, children and the elderly are considered environmentally vulnerable age groups. Scientific research puts forward that "for a given radiation dose, children are at more risk of tumour induction than are adults". ${ }^{24}$ This is also true for children's vulnerability to noise pollution. For example, the case of wind turbines and children is an interesting dilemma. Wind turbines are a widespread way of producing renewable energy. Renewable energy is considered crucial for keeping the environment clean for current children and future generations. However, differently from healthy adults, children who live in the vicinity of wind turbines face a risk of many developmental problems because of noise pollution, which is often disregarded by the policies about the noise level of wind turbines. ${ }^{25}$ Even the permitted noise levels in the WHO guidelines are criticised for disregarding those who may be more vulnerable to noise pollution, such as children. ${ }^{26}$

22 Karen P. DePauw, "Social-Cultural Context of Disability: Implications for Scientific Inquiry and Professional Preparation." Quest 52, no. 4 (2000): 358-68; Elizabeth Barnes, "Valuing Disability, Causing Disability." Ethics 125, no. 1 (2014): 88-113; Greg Bognar, "Is Disability Mere Difference?". Journal of Medical Ethics 42, no. 1 (2016): 46-49.

23 In an expert workshop in Geneva about the impacts of hazardous chemicals on women and children, leading global experts on chemicals and health asserted: "A specific policy focus on women with their different circumstances and needs in their role of protecting children from hazardous chemicals during their first months and years of development, -should exist but- is mostly non-existent". UNEP, "Women and Chemicals". Also see WHO. "Chemical Safety and Children's Health - Protecting the World's Children from Harmful Chemicals Exposures." 2016.

24 Committee, United Nations Scientific. "Sources, Effects and Risks of Ionizing Radiation, Scientific Annex B: Effects of Radiation Exposure on Children." 2013.

25 Arline L. Bronzaft, "The Noise from Wind Turbines: Potential Adverse Impacts on Children's Well-Being." Bulletin of Science, Technology \& Society 31, no. 4 (2011): 29195; Michael A. Nissenbaum, Jeffery J Aramini, and Christopher D Hanning. "Effects of Industrial Wind Turbine Noise on Sleep and Health." Noise and Health 14, no. 60 (2012): 237.

26 The guidelines recommend reducing noise levels produced by wind turbines below $45 \mathrm{~dB}$ $\mathrm{L}$ see http://www.euro.who.int/ data/assets/pdf file/0008/383921/noise-guidelines- 
Scientific studies also demonstrate that people older than 65 years are physically vulnerable to heatwaves and a high proportion of older people visit the emergency room after climate change-associated heatwaves. ${ }^{27}$ Women and their physiological environmental vulnerabilities have been another focus of scientific research. There is a large body of research indicating the connection between chemical exposures and breast cancer. ${ }^{28}$ Some chemicals trigger the hormonal changes that lead to breast cancer in women and, therefore, the exposure to the same chemicals by men is not as harmful. ${ }^{29}$

In sum, reports, social studies, and scientific studies indicate the link between environmental exposures and their discriminatory potential. Social studies highlight the environmental vulnerabilities that are created exogenously by the social structure. On the other hand, scientific studies indicate environmental vulnerabilities that come endogenously from the physiological conditions of individuals. Remarkably, the socially salient traits that these studies focus on match the socially salient traits that are present in the general equality and non-discrimination literature. Race, sex, and age have been the most prominent focuses of non-legal studies linking environmental exposures to discrimination. The next section explores the potential of discrimination law to address unequal impacts of environmental exposures.

\section{The Potential of Discrimination Law for Addressing Environmental Exposures}

Humans have been contributing to environmental degradation, especially since industrial societies were established. Major environmental law principles and a large body of environmental law have been developed

eng.pdf?ua=1(last accessed 15.04.2021). Lange does not find this limit suitable for children, see Lange, Sherri. "World Health Organization: Wind Turbine Noise as a Health Hazard (Opening Recognition Likely to Lead to More Acknowledgement)." MasterResource, 2018.

27 Sylvie Cassadou, et al. "Vague De Chaleur De L'été 2003: Relations Entre Températures, Pollution Atmosphérique Et Mortalité Dans Neuf Villes Françaises." Pollution atmosphérique 48, no. 191 (2006): 303-05;W Larry Kenney, Daniel H Craighead, and Lacy M Alexander. "Heat Waves, Aging, and Human Cardiovascular Health." Medicine and science in sports and exercise 46, no. 10 (2014): 1891.

28 Julia Green Brody, Joel Tickner, and Ruthann A. Rudel. "Community-Initiated Breast Cancer and Environment Studies and the Precautionary Principle." Environmental Health Perspectives 113, no. 8 (2005): 920-25; BCA. "What You Should Know About Breast Cancer \& the Environment." 2014.

29 BCA, "Breast Cancer". 
for the protection of the environment, i.e. air, water, and living beings. ${ }^{30}$ Environmental law, among other objectives, has a human health objective, which is to protect all humans from the detrimental effects of environmental degradation, e.g. air/water/noise pollution and products with harmful chemicals. ${ }^{31}$ There is a strong link between all sorts of environmental pollution and serious illnesses. EU environmental law has been particularly active in protecting human health. ${ }^{32}$

Distinctively from the general application of environmental law, the equality and non-discrimination aspects of environmental exposures mainly focus on groups of individuals who are particularly disadvantaged because of their socially salient traits. Thus, the scope of the issues that can be addressed by discrimination law is limited to the environmental law cases where a disparate impact on the health of individuals with socially salient traits can be identified.

The aspects of the link between the environment and the disadvantaged situation of individuals with socially salient traits are insufficiently subject to legal studies. There are numerous legal studies on the link between the environment and racial discrimination, especially in the US. ${ }^{33}$ There are a few legal studies on the link between the environment and age discrimination. ${ }^{34}$ There do not seem to be any sustained legal developments on other grounds such as sex, disability, or religion. There is a lack of legal studies that emphasise all aspects of environmental issues linked to the principle of equality. In other words, all environmental injustices having

30 Nicolas De Sadeleer, Environmental Principles: From Political Slogans to Legal Rules. Oxford University Press, 2002: 14-20; Peter GG. Davies, European Union Environmental Law: An Introduction to Key Selected Issues. Taylor \& Francis, 2017: 4-5.

31 Nicolas De Sadeleer, EU Environmental Law and the Internal Market. Oxford University Press, 2014: 36-37.

32 Ibid.

33 Carolyn M. Mitchell, "Environmental Racism: Race as a Primary Factor in the Selection of Hazardous Waste Sites." National Black Law Journal 12 (1990): 176; Peter L. Reich, "Greening the Ghetto: A Theory of Environmental Race Discrimination." University Kansas Law Review 41 (1992): 271; Tara. Ulezalka,"Race and Waste: The Quest for Environmental Justice." Temple Journal of Science, Technology \& Environmental Law 26 (2007): 51; Michael Gerrard, Law of Environmental Justice: Theories and Procedures to Address Disproportionate Risks. American Bar Association, 2008; Christopher D. Ahlers, "Race, Ethnicity, and Air Pollution: New Directions in Environmental Justice." Environmental Law 46, no. 4 (2016): 713-58.

34 Axel Gosseries, "Environmental Degradation as Age Discrimination." e-Pública 22 (2015); Refia Kaya, "Environmental Vulnerability, Age and the Promises of Anti-Age Discrimination Law." Review of European, Comparative \& International Environmental Law 28, no. 2 (2019a): 162-74. 
disparate impacts related to any socially salient traits have not been embraced by a single study so far.

The term "environmental discrimination" is used in this article to indicate the particular relationship between equality, discrimination law, and the environment. Environmental discrimination, as it is explored in non-legal studies, appears when environmental exposures cause an adverse impact on individuals with socially salient traits.

The distribution of environmental exposures, to a great extent, is/can be determined by state policies. Therefore, the state could have the responsibility with regard to environmental discrimination, based on the activities of both state actors and private actors whose activities should be regulated. For example, the state may abstain from challenging the disparate impacts of environmental exposures that are caused by state or private actors.

Prima facie, addressing the unequal distribution of environmental exposures through discrimination law may seem like a straightforward path. Theoretically, it may seem perfectly sensible to address them through discrimination law. However, environmental complaints do not generally tend to be framed as discrimination issues. To illustrate, there are numerous sex discrimination cases before the Court of Justice of the European Union (CJEU) concerning women's economically disadvantaged position in the working environment. ${ }^{35}$ However, there are not many lawsuits that challenge the environmentally disadvantaged position of women in the working environment and no cases with regard to the living environment. ${ }^{36}$

Similarly, before the European Court of Human Rights (ECtHR), there are numerous cases where environmental issues such as air pollution arising from industrial emissions, chemicals, airport construction, mining activities, and waste sites close to human settlements are associated with the right to life, right to property, and right to quality of life. ${ }^{37}$ However, among these

35 Cases on equal pay, part-time workers, parental leave, and quotas represent a large body of the case law, e.g. C-96/80, J.P. Jenkins v. Kingsgate (Clothing Productions) Ltd, ECLI:EU:C:1981:80; C-595/12, C-187/00, Helga Kutz-Bauer v Freie und Hansestadt Hamburg, ECLI:EU:C:2003:168; Loredana Napoli v Ministero della Giustizia Dipartimento dell'Amministrazione penitenziaria, ECLI:EU:C:2014:128.

36 There are no cases about the environmentally disadvantaged situation of women in their living environments. There are a few cases about workplace exposures and pregnant women, which will be referred to in this article.

37 Council of Europe, "Manuel on Human Rights and the Environment." 2012: 8. Right to life and right to property is used in a limited number of environmental cases. They are invoked when someone dies or property is severely damaged, e.g., Oneryildiz $v$. 
cases, those that are framed as equality and non-discrimination issues are very rare. ${ }^{38}$

This lack of interest in the potential of discrimination law to address environmental issues has started to change. The legal cases challenging climate change are good inspirations where the applicants frame the state's climate inaction as a discrimination issue. ${ }^{39}$ However, with the exception of

Turkey,Application no. 48939/99, 30 November 2004; Brincat and Others v. Malta, Application no. 60908/11, 24 July 2014. Most of the environmental cases are brought under Article 8 of the ECHR on the right to respect for private and family life. Environmental cases under Article 8 concern environmental challenges that do not pose a direct threat to life but affect the quality of life, e.g., López Ostra v. Spain, Application no. 16798/90, 9 December 1994; Hatton and Others v. the United Kingdom, Application no. 36022/97, 8 July 2003;Kyrtatos v. Greece, Application no. 41666/98, 22 May 2003; Jugheli and others v. Georgia, Application no. 38342/05, 13 July 2017.

38 In fact, there is only one case, Moldovan and Others v. Romania, Applications nos. 41138/98 and 64320/01,12 July 2005, concerning Roma minorities, which will be referred to later in this article.

39 In some of the current cases against climate change, applicants challenge the failure of governments to take action to increase climate mitigation/adaptation ambition. The applicants argue that the national litigation policies should be revised according to international targets. Some of these cases are as follows:

Juliana, et al. v. United States of America, et al. No: 6:15-cv-01517 (D.Or. 2018), where proceeding $§ 292$ states that:

"The affirmative aggregate acts of Defendants in the areas of fossil fuel production and consumption irreversibly discriminate against Plaintiffs' exercise of their fundamental rights to life, liberty, and property, and abridge central precepts of equality. The affirmative aggregate acts of Defendants in the areas of fossil fuel production and consumption have caused and are causing irreversible climate change. As a result, the harm caused by Defendants has denied Plaintiffs the same protection of fundamental rights afforded to prior and present generations of adult citizens".

Verein Klima Seniorinnen Schweiz v. Bundesrat (2016), https://ainees-climat.ch/ § 88 (last accessed 15.04.2021), which states that:

"Not everyone is equally affected by the consequences of excessive global warming, namely by heatwaves. In Switzerland, the excessive warming negatively has particular effects on a highly vulnerable population group: the group of older women, to which the Applicants belong".

T-330/18, Armonda Ferrao Carvalho and Others v. The European Parliament and Council of the European Union,ECLI:EU:T:2019:324. See page 27 of the application delivered to the CJEU at https://peoplesclimatecase.caneurope.org/wpcontent/uploads/2018/08/application-delivered-to-european-general-court.pdf(last accessed 15.04.2021), which states that:

"Article 21 of the Charter prohibits any discrimination based on age. This principle of equal treatment should clearly be applicable in respect of equality between children and young people, and older people, and requires broader intergenerational justice.... [U]nless drastic action is taken now, today's children will face environmental conditions in their future lives that are far worse than those enjoyed by present day adults". 
this body of case law, there is not much legal development in Europe that shows the use of discrimination law to address environmental issues.

The theoretically underdeveloped link between environment and discrimination can be one reason for this situation. Another reason can be the internal limits of discrimination law that make it unpractical to address environmental issues. This section briefly addresses the latter possibility. It indicates some of the limits and then discusses whether there are promises and advantages of discrimination law to address environmental issues.

There are at least two potential obstacles that can limit framing environmental issues as discrimination issues. ${ }^{40}$ The first obstacle is that environmental issues might pose a threat to the physical integrity of individuals through the state's abstention, i.e. inaction, rather than action. Environmental issues can but do not usually appear as a result of policies that directly treat a given race, sex, age, or any other traits wrongly. ${ }^{41}$ Hence, the most important tools to problematise environmental issues are studies showing the structural inequalities and the lack of willingness of the authorities to correct such inequalities. The distribution of waste sites is such an example. There could be a general policy consisting of putting waste sites

The State of the Netherlands v. Urgenda Foundation, ECLI:NL:GHDHA:2018:2610 [2018] Gerechtshof Den Haag, C/09/456689/ HA ZA 13-1396 § 37 states that:

"...it is without a doubt plausible that the current generation of Dutch nationals, in particular but not limited to the younger individuals in this group, will have to deal with the adverse effects of climate change in their lifetime if global emissions of greenhouse gases are not adequately reduced".

40 These problems also appear with regard to tort law. Many environmental problems can be framed through the language of harm, but it does not follow that in practice we rely much on tort law to address them. Two serious limitations in this regard are the difficulty of establishing causation and the requirement of a direct act or omission. See Gerald W. Boston, "A Mass-Exposure Model of Toxic Causation: The Content of Scientific Proof and the Regulatory Experience." Colombia Journal of Environmental Law 18 (1993): 181; Ken Oliphant, "Uncertain Factual Causation in the Third Restatement: Some Comparative Notes." William Mitchell Law Review 37, no. 3 (2010): 1599-632.

41 For example, one problem in the US is that in the discrimination cases that were brought both under the Constitution's 5th (due process) and 14th (equal protection) Amendments and Title VI of the 1964 Civil Rights Act, the US Courts ask for proof of "disparate treatment". This requires plaintiffs to reveal a very clear pattern of intentional discrimination, which has obstructed numerous environmental racism suits. Some of these are: Bean v. Southwestern Waste Management Corp., 482 F. Supp. 673 (S.D. Tex. 1979); East Bibb Twiggs v. MACON-BIBB CTY. P. \& Z. COM'N, 706 F. Supp. 880 (M.D. Ga. 1989); RISE, Inc. v. Kay, 768 F. Supp. 1144 (E.D. Va. 1991); Boyd v. Browner, 897 F. Supp. 590 (D.C. 1995); Rozar v. Mullis, 85 F.3d 556 (11th Cir. 1996);Miller v. City of Dallas, 2002 U.S. Dist. L.E.X.I.S. 2341 (2002);Cox v. City of Dallas, Tex., 430 F.3d 734 (5th Cir. 2005). 
far away from the city centre. If people from a particular race constitute the majority of those living outside the city centre, they may claim to be discriminated against. The problem is the same with air pollution policies. A general policy may take into consideration the level of pollution that could harm a healthy adult, but disregard the groups in society that are more sensitive to pollution, such as children and people with chronic diseases. Social and public health studies are important to reveal such inconsistent policies. The state can reinforce discrimination when social and scientific studies reveal a problem, but the state disregards it and does not take action. Does discrimination law have any promises or advantages to address such environmental issues?

Discrimination law allows re-describing differential treatments as inaction problems. For example, most of the indirect discrimination cases rely on the fact that no action was taken to correct an injustice that resulted from a general rule that was the same for everyone. ${ }^{42}$ In environmental discrimination cases, it can be assumed that, in fact, the state is disregarding socially vulnerable individuals and their claims. Thus, one can argue that the state has to prove genuinely legitimate reasons for not acting. The developments with regard to bringing indirect discrimination claims in European case law are an important promise of discrimination law ${ }^{43}$, which would facilitate framing environmental issues as discrimination cases.

The second potential obstacle to bringing environmental discrimination cases is the causation test. The causation test aims at determining the link between the treatment of the state or private actors and the victim's socially salient trait. ${ }^{44}$ Causation tests ask: How likely is it that the same health issues would have arisen in the absence of the influence of the state or private actors and the socially salient trait of the individual? It could be hard to establish a causation link between the damaging treatment and the disadvantaged situation that is faced by some individuals, mainly because environmental exposures can disadvantage individuals in the long term, and there could be a variety of factors affecting the health of individuals other than their socially salient trait. ${ }^{45} \mathrm{~A}$ strict causation test would require proving

42 Christa Tobler, Indirect Discrimination: A Case Study into the Development of the Legal Concept of Indirect Discrimination under EC Law. Social Europe Series. Intersentia, 2005: 61-62; Hugh Collins and Tarunabh Khaitan. "Indirect Discrimination Law: Controversies and Critical Questions." In Foundations of Indirect Discrimination Law, edited by Hugh Collins and Tarunabh Khaitan: Bloomsbury Publishing, 2018: 11-13.

43 Collins \&Khaitan, "Indirect Discrimination Law".

44 William Lloyd Prosser, Handbook of the Law of Torts. 4 ed.: West Publishing, 1971: 236237, 241.

45 Daniel A. Farber, "Toxic Causation." Minnesota Law Review 71 (1986): 1219; Boston, "Toxic Causation"; Oliphant, "Factual Causation". 
the motive of the state to environmentally harm certain groups of individuals and proving that individuals were disadvantaged only because of their socially salient traits. ${ }^{46}$ For example, a young individual may not be able to show that she will be the victim of environmental catastrophe because of the state's climate inaction. Because of this hardship, it is important to identify whether discrimination law offers any flexibility.

Discrimination law allows proving the disadvantaged situation related to environmental issues through statistical data that show the common vulnerability of people who share the same trait. This flexibility to prove causation is particularly relevant for European discrimination law. ${ }^{47}$ This would help to prove the causation between a given environmental challenge and the harm or the risk of harm. An individual would be allowed to claim that the state's inaction structurally disadvantages those who share the same trait with her. Even if the threat towards one individual is not severe enough, discrimination itself against a socially salient group can be an illegal treatment. This approach would help to prove causation between the state's treatment and the disadvantaged situation of individuals based on their socially salient trait. Hence, the promise of discrimination law is the development in the case law that helps to address structural disadvantages. ${ }^{48}$

So far, two potential obstacles to using discrimination law in environmental cases were identified. First, environmental issues may stem from the mere inaction of the state. Second, in some cases, the causal link between the treatment of the state or private actors and the victim's environmental disadvantage based on her socially salient trait cannot be directly established. It was demonstrated that the developments of European discrimination law with regard to indirect discrimination and the developments of the tools to address structural inequalities can help to overcome these obstacles. These two developments can be considered as an advantage of relying on discrimination law to address environmental issues. The legal advantages of framing environmental exposures as equality and discrimination issues should be further explored. ${ }^{49}$

46 Ibid.

47 Katerina Linos, "Path Dependence in Discrimination Law: Employment Cases in the United States and the European Union." Yale Journal of International Law 35 (2010): 115.

48 Egbert Willem Vierdag, The Concept of Discrimination in International Law: With Special Reference to Human Rights. Martinus Nijhoff, The Hague, 1973; Cass R. Sunstein, The Partial Constitution. Harvard University Press, 1993: 68-92; Tobler, "Indirect Discrimination", 61-62; Collins \& Khaitan, "Indirect Discrimination Law, 11-13.

49 For example, consider the ECtHR's Fägerskiöld case about wind turbines and wind energy farms constructed close to the applicant's house. The applicant complained that the noise and light reflections from the turbines were affecting his quality of life negatively and, 
The following sections scrutinise possible ways of framing many of the environmental cases that we have in mind as equality and non-discrimination issues and whether Europeancase law on discrimination includes promising legal cases. In other words, what kind of environmental exposures could be considered problematic under discrimination law? This question is discussedin the following sections through two stylised examples of environmental exposures related to environmental exposures at work and environmental exposures at living environment, respectively.

\section{Environmental Exposures at Work and European Discrimination Law}

Consider that some women avoid becoming interventional radiologists, even if they desire to, because of the possible effects of the radiation on the foetus if they become pregnant. ${ }^{50}$ Some women take the risk, if this is the only suitable job that they can do, if it is their best option, or if their desire to become an interventional radiologist is strong enough. Women are expected to take the risk or not do this job at all. ${ }^{51}$ Moreover, some employers avoid hiring women who are/could be pregnant since they do not want to put forth extra effort to make sure that these women are safe and healthy.This could lead to a, at least, twofold problem, i.e. this may be problematised in at least two ways as an equality issue and as a discrimination issue..$^{52}$

therefore, violated Article 8. The ECtHR referred to the guidelines of the World Health Organisation (WHO), which recommend a maximum level of noise suitable for human health. Apparently, the noise levels of the wind turbines were not exceeding the recommendation of the WHO.

The ECtHR held that:

"the nuisance caused to the applicants by the wind turbine cannot be considered so severe as to affect them seriously or impinge on their enjoyment of their property. In relation to the interests of the community as a whole, the Court reiterates that wind power is a renewable source of energy which is beneficial for both the environment and society". Fägerskiöld v. Sweden,Application no. 37664/04, 26 February 2008. See also a parallel case: Vecbaštika and Others v. Latvia, Application no. 52499/11, 19 November 2019.

Considering that the WHO guidelines are criticised for disregarding children and other vulnerable groups when advising the given noise level, would the conclusion of this case have changed if the applicant had claimed the existence of discrimination against his children? Such questions need to be explored.

50 This example is based on contemporary scientific studies. See Catherine T. Vu and Deirdre H. Elder, "Pregnancy and the Working Interventional Radiologist." Seminars in Interventional Radiology 30, no. 4 (2013): 403-07.

51 Ibid.

52 It is possible that some will not see any breach of rights, because they believe that the state should not intervene in such a problem. If women choose to do a job that involves 
First, the reproductive health of women, the health of expectant mothers and their babies are put in jeopardy. Radiation could be a threat to reproductive health of women in general and expectant mothers especially when the existing exposure limits are not safe for them although being safe for other individuals. Hence, right to equality and non-discrimination can be breached since women cannot be as safe as others at work because of their socially salient trait. The problem related to equality and non-discrimination would be solved if the state prohibits women who are/could become pregnant from doing jobs that put them and their babies in jeopardy. Even if some women choose to do a given job, they would not be allowed. By eliminating women who are/could be pregnant from working environments with environmental exposures, there would be no problem of equality and non-discrimination with regard to differential effects of exposures because the risk group would not be present in such working environments. This could be one way of preventing environmental discrimination. This is a strategy that restricts the opportunity of women to become interventional radiologists. Such a strategy would not require employers to make reasonable accommodations for female workers to make sure that they are safe and healthy during pregnancy because women will not be allowed to work in jobs with environmental exposures that could be dangerous to them. However, such a solution can be discriminative.

In this regard the second way to frame discrimination issue is that the freedom and options of women who are/could become pregnant to choose a suitable job and, subsequently, their presence in the job market could be restricted. This could be either because women want to avoid the risk or because employers are not hiring women who are/could be pregnant to avoid any unpleasant health situations and related tort cases. Hence, the right to equality and non-discrimination breached since women cannot choose the job that they want as freely as others, and subsequently, they cannot be as represented as others. Under this approach, the state could oblige employers to make the working environments equally safe for all. There could be regulations regulating exposure limits for pregnant workers. There could be a requirement to take positive action to support pregnant workers, such as temporarily changing the duty of women who become pregnant to something that has no dangerous exposures or offering women extra leave. ${ }^{53}$ Applying

environmental exposures, this is their own choice, i.e. they voluntarily take the risk. The state should only make sure that women are well informed about the risk. It is also possible that some will not consider the problem against the right to equality and nondiscrimination. I do not discuss such arguments.

53 Patricia J. M. Best, et al. "Scai Consensus Document on Occupational Radiation Exposure to the Pregnant Cardiologist and Technical Personnel." Heart, Lung and Circulation 20, no. 2 (2011/02/01/ 2011): 87-88. 
such measures would require ensuring that employers are not structurally disadvantaging women in the recruitment process to escape from the burden of accommodation.

Under EU law, there is an obligation to pay particular attention to the safety of pregnant workers in working environments. Directive 92/85/EEC of 19 October 1992 " on the introduction of measures to encourage improvements in the safety and health at work of pregnant workers and workers who have recently given birth or are breastfeeding" brings such an obligation. ${ }^{54}$ In the related CJEU case of Elda Otero Ramos (2017), the CJEU found that the equality of opportunity principle and equal treatment principle require "improvements in the safety and health at work of pregnant workers and workers who have recently given birth or are breastfeeding". As the CJEU puts it:

“Article 19(1) of Directive 2006/54/EC of the European Parliament and of the Council of 5 July 2006 on the implementation of the principle of equal opportunities and equal treatment of men and women in matters of employment and occupation must be interpreted as applying to a situation such as that at issue in the main proceedings, in which a breastfeeding worker challenges, before a court or other competent authority of the Member State concerned, the risk assessment of her work in so far as she claims that the assessment was not conducted in accordance with Article 4(1) of Council Directive 92/85/EEC of 19 October 1992 on the introduction of measures to encourage improvements in the safety and health at work of pregnant workers and workers who have recently given birth or are breastfeeding." 55

The existing literature on this case reveals that the case is not analysed as an environmental discrimination issue. ${ }^{56}$ However, this case is important to foresee the approach of the CJEU for the discussions carried out in this section. It seems that the CJEU would diagnose the issue of female radiologists as an issue concerning the concept of equality of opportunity. It is clear that the CJEU requires the responsible authorities to ensure a safe working environment for pregnant women. ${ }^{57}$ However, the personal scope of the related regulation is limited to pregnancy. It does not cover all socially

54 Directive 92/85/EEC, OJ 1992 L 348.

55 See C-531/15,Elda Otero Ramos v. Servicio Galego de Saúde, Instituto Nacional de la Seguridad Social, ECLI:EU:C:2017:789. A more recent parallel case is C-41/17, Isabel González Castro v. Mutua Umivale, Prosegur España SL, Instituto Nacional de la Seguridad Social (INSS), ECLI:EU:C:2018:736.

56 Ángel Arias Domínguez, "Chronicles of International Labor Jurisprudence ". Cuadernos Derecho Transnacional 10 (2018).

57 Directive 92/85/EEC, OJ 1992 L 348/1. 
salient traits, such as age, disability, or race, that could bring vulnerabilities to environmental exposures. Moreover, there is no similar case that has come before the ECtHR about safety at work and discrimination against those with socially salient traits. The next section explores environmental exposures in the living environment.

\section{Environmental Exposures in the Living Environment and European Discrimination Law}

Consider that the state builds wind turbines to produce renewable energy to keep the environment clean for children and future generations. The permitted noise levels are determined by the tolerance level of an average adult. However, children are less tolerant of the noise levels of wind turbines than healthy adults are. It appears that children who live in the vicinity of the wind turbines face a risk of developmental problems because of noise pollution. ${ }^{58}$

Environmental exposures in living environments can be related to equality and discrimination if the state's inaction to eliminate environmental exposures has an adverse effect on individuals with a particular socially salient trait. In the example of wind turbines, such a link is established. Although this example is different than the example of safety at work, a similar analysis with regard to the different concepts of equality is relevant. This exposure case could lead to the following problems:

First, children who live in the vicinity of wind turbines would be physically and mentally harmed. Right to equality and non-discrimination can be breached because of the adverse effects of wind turbines on children. Second, children who face developmental disorders would have less success in schools, and subsequently, they might be less able to achieve good positions. Hence, right to equality and non-discrimination can also be breached since children who are the victims of noise pollution might be deprived of the chance to develop their talents.

There is a limited amount of European law on the link between children and pollution of the living environment. EU law does not disregard the fact that some vulnerable groups may need special measures. For example, in the EU, Article 23 of Directive 2008/50 on "air quality plans" includes the aim of protecting sensitive population groups, including children. ${ }^{59}$ In the

58 This example is based on a contemporary problem. SeeBronzaft, "Wind Turbines"; Nissenbaum, "Wind Turbine".

${ }^{59}$ Directive 2008/50/EC, 2008 OJ L152/1. 
ClientEarth (2014) case, the CJEU confirmed this directive by declaring that "air quality plans may additionally include specific measures aiming at the protection of sensitive population groups, including children". ${ }^{60}$ In that case, the CJEU held that states may include special measures. Hence, both the directive and the related case do not require special measures for children. They only allow and encourage special measures that take vulnerable populations into consideration.

There is a case against the climate change policies of the EU, the Carvalho (2019) case, where the plaintiffs, for the first time, linked environmental exposure in the living environment to age discrimination against children. In this ongoing case, the applicants claimed that:

"Article 21 of the Charter prohibits any discrimination based on age. This
principle of equal treatment should clearly be applicable in respect of
equality between children and young people, and older people, and requires
broader intergenerational justice... [U]nless drastic action is taken now,
today's children will face environmental conditions in their future lives that
are far worse than those enjoyed by present day adults". ${ }^{61}$

It is not certain how the CJEU would react to this claim based on the directive on age discrimination. However, based on the precedent of the CJEU on air pollution and children, the CJEU would allow but not require states to take the vulnerability of children into consideration. This does not mean that there are no possible legal avenues to claim a requirement to challenge environmental discrimination against children. Some strategies can be developed. ${ }^{62}$

The ECtHR case law concerning environmental discrimination is underdeveloped. It is limited to an environmental discrimination case on the grounds of race and in the domain of the living environment. The Moldovan (2005) case concerns the degrading circumstances in which Roma people lived after their houses had burned. ${ }^{63}$ The ECtHR recognised that:

${ }^{60}$ C-404/13, ClientEarth v. The Secretary of State for the Environment, Food and Rural Affairs, ECLI:EU:C:2014:2382.

${ }^{61}$ T-330/18, Armonda Ferrao Carvalho and Others $v$. The European Parliament and Council of the European Union,ECLI:EU:T:2019:324. See page 27 of the application delivered to the CJEU at https://peoplesclimatecase.caneurope.org/wpcontent/uploads/2018/08/application-delivered-to-european-general-court.pdf(last accessed 15.04.2021). This case was opened in 2018 and was refused on procedural grounds. It is currently in appeal.

${ }^{62}$ See the possible strategies for age discrimination law in Kaya, "Anti-Age Discrimination Law."

${ }^{63}$ There is another case, Chapman v. United Kingdom,Application No. 27238/95, 18 January 2001, related to Roma/“Gypsy” people being victims of the pro-environmental policies of 
“the applicants' living conditions in the last ten years, in particular the severely overcrowded and unsanitary environment and its detrimental effect on the applicants' health and well-being, combined with the length of the period during which the applicants have had to live in such conditions and the general attitude of the authorities, must have caused them considerable mental suffering, thus diminishing their human dignity and arousing in them such feelings as to cause humiliation and debasement..."64

The ECtHR held that the right to equality and non-discrimination of Article 14 was violated. In this case, given the severity of the conditions that the applicants faced, there were other rights that were breached in the absence of a discrimination claim. Here, the contribution of the discrimination claim does not look straightforward because the applicants were living in extremely degrading and very harsh conditions. Hence, the ECtHR found the violation of Article 3 on "prohibition on torture" alone. Still, the link established between the bad environmental conditions that the applicants lived in and racial discrimination is important for opening an avenue for potential environmental discrimination cases. ${ }^{65}$

Different types of cases have been explained so far. One type of case concerned the vulnerability of some individuals in the domain of the working environment, and another type of case concerned the vulnerability

the state because of their traveller lifestyle. This is not a case about a challenge that they face because of environmental degradation or environmental convictions; it is about a challenge they face regarding pro-environmental policies. The applicant brought the case against the restrictions placed upon the accommodations available to Roma/Traveller people. The applicant urged the ECtHR to consider that, according to international obligations, the security, identity, and lifestyle of minorities should be protected. The ECtHR recognised such obligations but held that:

"the complexity and sensitivity of the issues involved in policies balancing the interests of the general population, in particular with regard to environmental protection, and the interests of a minority with possibly conflicting requirements renders the Court's role a strictly supervisory one" $(\S 93)$.

Seven judges disagreed, stating that: "There is an emerging consensus amongst the member States of the Council of Europe recognising the special needs of minorities and an obligation to protect their security, identity and lifestyle (...in particular the Framework Convention for the Protection of National Minorities), not only for the purpose of safeguarding the interests of the minorities themselves but also in order to preserve a cultural diversity of value to the whole community. We cannot therefore agree with the majority's...conclusion that the complexity of the competing interests renders the Court's role a strictly supervisory one" (Joint Dissenting Opinion $\S 3$ ).

${ }^{64}$ Moldovan and Others v. Romania, Applications nos. 41138/98 and 64320/01, 12 July 2005 $\S 110,113$.

65 Refia Kaya, "European Court of Human Rights on Addressing Environmental Discrimination against Collectivities ". The Lawyer Quarterly 9, no. 4 (2019b). 
of some individuals in the living environment. I have demonstrated that European legislation and case law are not developed enough to address each type of environmental discrimination case referred to in this article (see table 1). However, some non-environmental cases can inspire us to develop legal strategies to address environmental discrimination.

Table Number 1: Environmental discrimination cases

\begin{tabular}{|l|l|l|}
\hline & Related Sections & Legal Cases \\
\hline $\begin{array}{l}\text { Vulnerability in the } \\
\text { working environment }\end{array}$ & III & $\begin{array}{l}\text { Elda Otero Ramos (2017) } \\
\text { (CJEU) }\end{array}$ \\
\hline $\begin{array}{l}\text { Vulnerability in the living } \\
\text { environment }\end{array}$ & IV & $\begin{array}{l}\text { ClientEarth (2014) } \\
\text { (CJEU) } \\
\text { Carvalho (2019) (CJEU) } \\
\text { Moldovan } \\
\text { (ECtHR) }\end{array}$ \\
\hline
\end{tabular}

\section{Conclusion}

This article has two main findings. First, there are good non-legal and legal reasons to use discrimination law in environmental exposure cases. The reason is that there are already a large amount of social and scientific studies showing that environmental exposures are affecting individuals differently based on their socially salient traits, such as race, age, sex. These studies have the potential to inspire the use of discrimination law to address environmental exposures. However, the second finding of this article is that, the use of discrimination law in environmental cases is not common before the European Courts, although the possible legal obstacles that were identified, e.g. the causation test, do not seem like a concern. Still, there are few cases to show the possible approach of the European Courts to the link between environmental exposures and discrimination. These cases are limited in scope and application. Hence, the most appropriate methodology to explore the potential of discrimination to address environmental exposures seems to be the following: first, exploring the approach of the Courts in nonenvironmental discrimination cases, and second, discussing whether the given approach can be helpful to address environmental exposures.

In this era of growing environmental crisis, alternative avenues are needed to address environmental exposures. ${ }^{66}$ In this respect, discrimination

66 For example, with regard to climate-related challenges, climate scientists put forward that "litigate-to-mitigate campaign is needed alongside political mobilization". This is mainly because, especially in Europe, the Courts have the power to push politicians to act. See "'We should be on the offensive' - James Hansen calls for wave of climate lawsuits", 
law seems like a promising avenue to address the environmental exposures to which vulnerable groups are predisposed. Thus, it needs to be further explored how the debate on the concepts of equality can contribute to both the practice of discrimination law and the particular use of discrimination law in environmental cases.

\section{BIBLIOGRAPHY}

Ahlers, Christopher D. "Race, Ethnicity, and Air Pollution: New Directions in Environmental Justice."Environmental Law 46, no. 4 (2016): 713-58.

Barnes, Elizabeth. "Valuing Disability, Causing Disability."Ethics 125, no. 1 (2014): 88-113.

BCA. "What You Should Know About Breast Cancer \& the Environment." 2014.

Best, Patricia J. M., et al. "Scai Consensus Document on Occupational Radiation Exposure to the Pregnant Cardiologist and Technical Personnel."Heart, Lung and Circulation 20, no. 2 (2011/02/01/2011): 83-90.

Bognar, Greg. "Is Disability Mere Difference?". Journal of Medical Ethics 42, no. 1 (2016): 46-49.

Boston, Gerald W. "A Mass-Exposure Model of Toxic Causation: The Content of Scientific Proof and the Regulatory Experience."Colombia Journal of Environmental Law 18 (1993): 181.

Brody, Julia Green, Joel Tickner, and Ruthann A. Rudel. "Community-Initiated Breast Cancer and Environment Studies and the Precautionary Principle."Environmental Health Perspectives 113, no. 8 (2005): 920-25.

Bronzaft, Arline L. "The Noise from Wind Turbines: Potential Adverse Impacts on Children's Well-Being."Bulletin of Science, Technology \& Society 31, no. 4 (2011): 291-95.

Bullard, Robert D. Dumping in Dixie: Race, Class, and Environmental Quality. Boulder: Westview Press, 1990.

Calderon, Rebecca L, et al. "Health Risks from Contaminated Water: Do Class and Race Matter?". Toxicology and Industrial Health 9, no. 5 (1993): 879-900.

Cassadou, Sylvie, et al. "Vague De Chaleur De L'été 2003: Relations Entre Températures, Pollution Atmosphérique Et Mortalité Dans Neuf Villes Françaises." Pollution atmosphérique 48, no. 191 (2006): 303-05.

https://www.theguardian.com/environment/2017/nov/17/we-should-be-on-the-offensivejames-hansen-calls-for-wave-of-climate-lawsuits? $\mathrm{CMP}=$ share btn tw(last accessed 15.04.2021). 
Collins, Hugh, and Tarunabh Khaitan. "Indirect Discrimination Law: Controversies and Critical Questions." In Foundations of Indirect Discrimination Law, edited by Hugh Collins and Tarunabh Khaitan: Bloomsbury Publishing, 2018.

Committee, United Nations Scientific. "Sources, Effects and Risks of Ionizing Radiation, Scientific Annex B: Effects of Radiation Exposure on Children." 2013.

Council of Europe. "Manuel on Human Rights and the Environment." 2012.

Dankelman, Irene. Gender and Climate Change: An Introduction. London: Earthscan, 2010.

Davies, Peter GG. European Union Environmental Law: An Introduction to Key Selected Issues. Taylor \& Francis, 2017.

De Sadeleer, Nicolas. Environmental Principles: From Political Slogans to Legal Rules. Oxford University Press, 2002.

De Sadeleer, Nicolas. EU Environmental Law and the Internal Market. Oxford University Press, 2014.

DePauw, Karen P. "Social-Cultural Context of Disability: Implications for Scientific Inquiry and Professional Preparation."Quest 52, no. 4 (2000): 358-68.

Domínguez, Ángel Arias. "Chronicles of International Labor Jurisprudence ". Cuadernos Derecho Transnacional 10 (2018): 781.

Farber, Daniel A. “Toxic Causation.”Minnesota Law Review 71 (1986): 1219.

Fineman, Martha Albertson. "The Vulnerable Subject: Anchoring Equality in the Human Condition."Yale Journal of Law \& Feminism 20, no. 1 (2008): 2.

GAO. "Siting of Hazardous Waste Landfills and Their Correlation with Racial and Economic Status of Surrounding Communities." 1983.

Gerrard, Michael. Law of Environmental Justice: Theories and Procedures to Address Disproportionate Risks. American Bar Association, 2008.

Gosseries, Axel. "Environmental Degradation as Age Discrimination."e-Pública 22 (2015).

Harris, Angela P. "Vulnerability and Power in the Age of the Anthropocene."Washington and Lee Journal of Energy, Climate, and the Environment 6, no. 1 (2014).

Kaya, Refia. "Environmental Vulnerability, Age and the Promises of Anti-Age Discrimination Law."Review of European, Comparative \& International Environmental Law 28, no. 2 (2019a): 162-74.

Kaya, Refia. "European Court of Human Rights on Addressing Environmental Discrimination against Collectivities “. The Lawyer Quarterly 9, no. 4 (2019b). 
Kenney, W Larry, Daniel H Craighead, and Lacy M Alexander. "Heat Waves, Aging, and Human Cardiovascular Health."Medicine and science in sports and exercise 46, no. 10 (2014): 1891.

Khaitan, Tarunabh. A Theory of Discrimination Law. Oxford University Press, 2015.

Khoday, Kishan, and Leisa Perch. "Green Equity: Environmental Justice for More Inclusive Growth."Policy Research Brief, International Policy Centre for Inclusive Growth 19 (2012).

Lange, Sherri. "World Health Organization: Wind Turbine Noise as a Health Hazard (Opening Recognition Likely to Lead to More Acknowledgement)." MasterResource, 2018.

Linos, Katerina. "Path Dependence in Discrimination Law: Employment Cases in the United States and the European Union."Yale Journal of International Law 35 (2010): 115.

Lippert-Rasmussen, Kasper.Born Free and Equal?: A Philosophical Inquiry into the Nature of Discrimination. Oxford University Press, 2014.

Mitchell, Carolyn M. "Environmental Racism: Race as a Primary Factor in the Selection of Hazardous Waste Sites."National Black Law Journal 12 (1990): 176.

Nash, Roderick Frazier. The Rights of Nature: A History of Environmental Ethics. University of Wisconsin Press, 1989.

Nissenbaum, Michael A, Jeffery J Aramini, and Christopher D Hanning. "Effects of Industrial Wind Turbine Noise on Sleep and Health."Noise and Health 14, no. 60 (2012): 237.

Northridge, Mary E, and Peggy M Shepard. "Environmental Racism and Public Health."American Journal of Public Health 87, no. 5 (1997): 730-32.

Oliphant, Ken. "Uncertain Factual Causation in the Third Restatement: Some Comparative Notes."William Mitchell Law Review 37, no. 3 (2010): 1599-632.

Open Society Institute. "On the Margins: Roma and Public Services in Romania, Bulgaria and Macedonia." New York, 2001.

Prosser, William Lloyd. Handbook of the Law of Torts. 4 ed.: West Publishing, 1971.

Reich, Peter L. "Greening the Ghetto: A Theory of Environmental Race Discrimination. "University Kansas Law Review 41 (1992): 271.

Shiva, Vandana. "The Impoverishment of the Environment: Women and Children Last." In Ecofeminism, edited by Maria and Shiva Mies, Vandana, 70-91: Zed Books, 1993. 
Shrader-Frechette, Kristin. Environmental Justice: Creating Equality, Reclaiming Democracy. Oxford University Press, 2002.

Sunstein, Cass R. The Partial Constitution. Harvard University Press, 1993.

Tobler, Christa. Indirect Discrimination: A Case Study into the Development of the Legal Concept of Indirect Discrimination under EC Law. Social Europe Series. Intersentia, 2005.

UCC. "Toxic Wastes and Race in the United States: A National Report on the Racial and Socio-Economic Characteristics of Communities with Hazardous Waste Sites.", 1987.

Ulezalka, Tara. "Race and Waste: The Quest for Environmental Justice.”Temple Journal of Science, Technology \& Environmental Law 26 (2007): 51.

UNEP. "Women and Chemicals: The Impact of Hazardous Chemicals on Women: A Thought Starter Based on an Experts“ Workshop." 2016.

Vierdag, Egbert Willem. The Concept of Discrimination in International Law: With Special Reference to Human Rights. Martinus Nijhoff, The Hague, 1973.

$\mathrm{Vu}$, Catherine T., and Deirdre H. Elder. "Pregnancy and the Working Interventional Radiologist. "Seminars in Interventional Radiology 30, no. 4 (2013): 403-07.

Warren, Karen. Ecofeminist Philosophy: A Western Perspective on What It Is and Why It Matters. Rowman \& Littlefield, 2000.

WHO. "Chemical Safety and Children's Health - Protecting the World's Children from Harmful Chemicals Exposures.” 2016.

WHO. "Social and Gender Inequalities in Environment and Health.” 2010.

Wilson, Sacoby M. "Environmental Justice Movement: A Review of History, Research, and Public Health Issues.”Journal of Public Management \& Social Policy 16, no. 1 (2010).

Wing, Steve. "Environmental Justice, Science and Public Health."Environ Health Perspectives 113 (2005): 54-63. 
